\title{
Mobile left atrial round mass free floating in mitral regurgitation flow mimicking a whale spray
}

\author{
Atsuko Tahara, Nobuhiro Tahara, Akihiro Honda, Tsutomu Imaizumi
}

Division of Cardio-Vascular Medicine, Department of Medicine, Kurume University School of Medicine, Kurume, Japan

\section{Correspondence to} Dr Nobuhiro Tahara, ntahara@med.kurume-u.ac.jp

Accepted 10 February 2014

\section{DESCRIPTION}

A 77-year-old man with a history of atrial fibrillation presented with bilateral loss of vision. A CT scan revealed acute cerebral infarction in the left occipital lobe. Cardiogenic embolic stroke was diagnosed. Treatment with intravenous heparin and antioxidative radical scavenger, edaravone and oral warfarin was started. Nevertheless, he developed new aphasia, right-sided paralysis and left conjugate deviation of the eyes 3 weeks later. MRI revealed a new cerebral infarction in his temporal lobe. He was admitted to our hospital for further investigation and treatment. The ejection fraction of the left ventricle was measured as $79 \%$ by transthoracic echocardiography and there was moderate mitral regurgitation. Transoesophageal echocardiography revealed the presence of a $28 \times 38 \mathrm{~mm}$ round mass, possibly a thrombus in the left atrium, suggesting that embolisation was the cause of the stroke (figure 1A,B, arrows). The round mass was free floating in the mitral regurgitation flow, mimicking a whale spray above the mitral valve orifice without mural attachment (figure 1B, arrows, arrowhead and video 1). The patient received aggressive anticoagulation therapy, but did not undergo a surgical operation to remove the mobile mass because of a

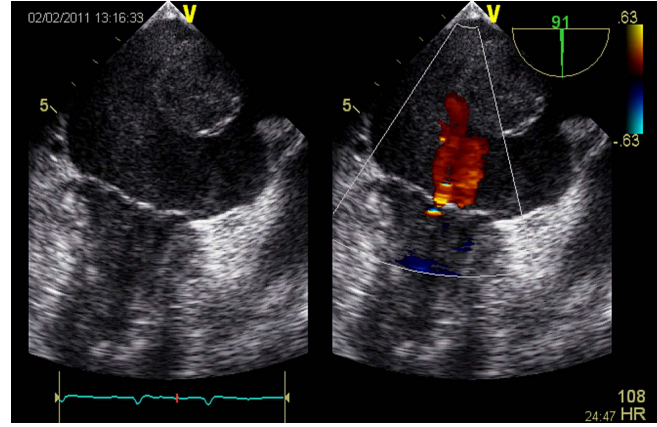

Video 1 The round mass was floating in mitral regurgitation flow above the mitral valve orifice (mimicking a whale spray).

decreased level of consciousness. He died after returning to the referral hospital. A left atrial mass may result in sudden circulatory collapse. ${ }^{1}$ Transoesophageal echocardiography imaging allows unique visualisation of masses and determination of size, shape, motion and spatial orientation within the left atrium. ${ }^{2}$ Surgical removal of a mobile left atrial mass should be performed before the occurrence of a fatal embolism.
CrossMark

To cite: Tahara $A$ Tahara N, Honda A, et al. BMJ Case Rep Published online: [please include Day Month Year] doi:10.1136/ bcr-2013-202725
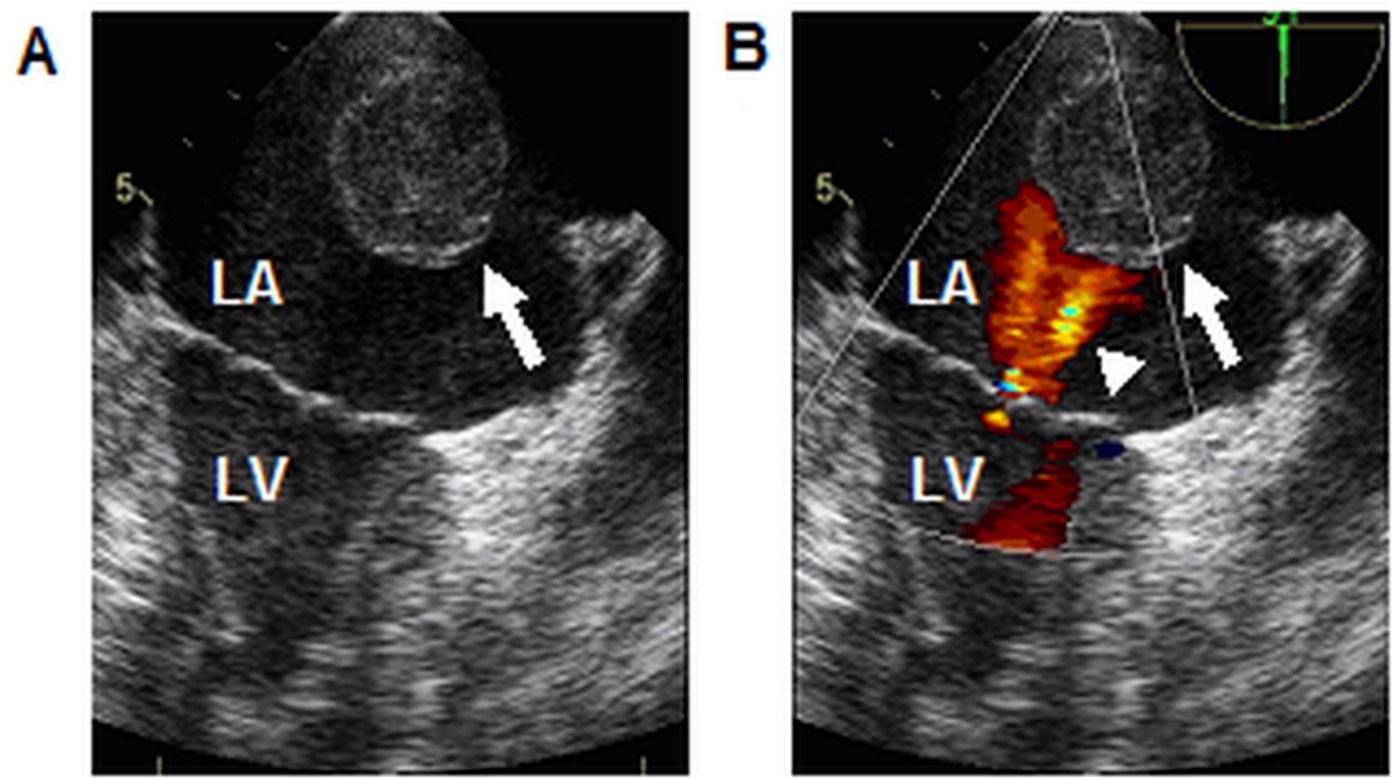

Figure 1 Transoesophageal echocardiography showing a round mass (A) floating in mitral regurgitation flow (B) (LA, left atrium; LV, left ventricle). 


\section{Learning points}

- Mobile left atrial mass is associated with a high risk of recurrence of whole-body embolism, especially cardiogenic embolic stroke.

- Transoesophageal echocardiography imaging provides detailed information of a mobile mass in the left atrium.

- Surgical removal of a mobile left atrial mass should be performed before the occurrence of a fatal embolism.
Contributors AT, AH and NT were involved in patient care and prepared manuscript and images. TI was in charge of patient care and final editing of the manuscript. All authors read and approved the final manuscript.

Competing interests None.

Patient consent Obtained.

Provenance and peer review Not commissioned; externally peer reviewed.

\section{REFERENCES}

1 Fujiwara $M$, Watanabe $H$, Oguma $Y$, et al. A free-floating left atrial thrombus develops intermittent entrapment in the mid-ventricle during diastole. Heart Vesse/s 2012;27:428-31.

2 Ando T, Abe H, Ro D. Case of embolism due to a floating thrombus migrating from the left atrial appendage to the ostium of the celiac artery. Ann Vasc Dis 2012;5:229-32.

Copyright 2014 BMJ Publishing Group. All rights reserved. For permission to reuse any of this content visit http://group.bmj.com/group/rights-licensing/permissions.

BMJ Case Report Fellows may re-use this article for personal use and teaching without any further permission.

Become a Fellow of BMJ Case Reports today and you can:

- Submit as many cases as you like

- Enjoy fast sympathetic peer review and rapid publication of accepted articles

- Access all the published articles

- Re-use any of the published material for personal use and teaching without further permission

For information on Institutional Fellowships contact consortiasales@bmjgroup.com

Visit casereports.bmj.com for more articles like this and to become a Fellow 